\title{
A Monte-Carlo approach to estimating the effects of selected airport capacity options in London.
}

Daniel Irvine, Lucy C.S. Budd and David E. Pitfield.

Transport Studies Group,

School of Civil \& Building Engineering

Loughborough University,

Loughborough, LE11 3TU

U.K.

D.E.Pitfield@lboro.ac.uk

\begin{abstract}
The issue of future airport capacity in London is currently the subject of much political debate in the UK. Through the use of Monte Carlo simulation, the paper quantifies and compares the relative capacity enhancements that may be afforded by the construction of a new hub airport, additional runways at Heathrow, Gatwick and Stansted and changes to operating practices at Heathrow. The simulations indicate that a new hub airport would be the most effective way to increase capacity, although the reported financial and environmental costs of such a development suggest a comparatively poor rate of return. Proposed new runways at Heathrow, Gatwick and Stansted and the removal of runway alternation at Heathrow provide more modest increases in capacity.
\end{abstract}

Keywords: airport capacity, Monte Carlo simulation, London, UK.

\section{Introduction}

Debates surrounding the provision of future airport capacity in London and the South East have had a long and controversial pedigree with the issue polarised between those who claim connectivity is vital for economic growth and those who believe that 
airport expansion creates an unjustifiable social and environmental burden. At the time of writing, a UK Government-appointed Airports Commission, chaired by Sir Howard Davies, is evaluating a number of possible options to enhance airport capacity in London and the south east. This paper employs Monte Carlo simulation to provide estimations of the relative effect on airport capacity that five proposals, which are all reportedly under consideration, afford. These proposals are: the development of a new hub airport in the Thames Estuary (as advocated by the Mayor of London); additional runways at Heathrow (either to the north or the west of the existing airport); a second runway at Gatwick; a second runway at Stansted; and the adoption of mixed mode operations at Heathrow.

\section{Method}

The first step in the simulation is to define the variables that will be randomised, in this case the traffic mix at an airport. Inbound and outbound aircraft must be separated according to size to enable potentially dangerous wake vortices to dissipate. Larger aircraft create more wake turbulence than smaller aircraft and consequently each aircraft type is assigned to a wake turbulence category to ensure safe separation is maintained. The traffic mix at an airport thus directly influences its capacity. At London Heathrow, for example, the majority of aircraft are Lower Medium or Heavy airframes (Table 1).

Table 1 - Traffic mix and aircraft probabilities for Heathrow

\begin{tabular}{|l|l|r|l|}
\hline $\begin{array}{l}\text { Aircraft } \\
\text { category }\end{array}$ & $\begin{array}{l}\text { Percentage } \\
\text { of } \\
\text { movements }\end{array}$ & Probability & $\begin{array}{l}\text { Cumulative } \\
\text { Probability }\end{array}$ \\
\hline Light (L) & $0 \%$ & 0 & 0 \\
\hline
\end{tabular}




\begin{tabular}{|l|r|r|r|}
\hline Small b (Sb) & $0.2 \%$ & 0.002 & 0.002 \\
\hline Small c (Sc) & $2 \%$ & 0.02 & 0.022 \\
\hline $\begin{array}{l}\text { Lower } \\
\text { Medium (LM) }\end{array}$ & $60.4 \%$ & 0.604 & 0.626 \\
\hline $\begin{array}{l}\text { Upper } \\
\text { Medium (UM) }\end{array}$ & $2.3 \%$ & 0.023 & 0.649 \\
\hline Heavy c (Hc) & $16.15 \%$ & 0.1615 & 0.8105 \\
\hline Heavy d (Hd) & $16.15 \%$ & 0.1615 & 0.972 \\
\hline Super (J) & $2.8 \%$ & 0.028 & 1 \\
\hline
\end{tabular}

Source: ???

Each aircraft in the simulation is assigned a random number which is married to the cumulative probability column in Table 1 to assign a wake turbulence category. This process is then repeated to simulate peak hour flows. A separation distance for each aircraft is defined according to international metrics (Table 2).

Table 2 - Separation times for arriving aircraft (in minutes).

\begin{tabular}{|c|c|c|c|c|c|c|c|c|c|}
\hline & \multicolumn{9}{|c|}{ Following Aircraft } \\
\hline \multirow{7}{*}{ 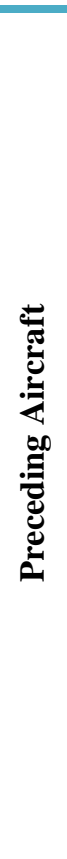 } & & $\begin{array}{l}\text { Super } \\
\text { (J) }\end{array}$ & $\begin{array}{l}\text { HeavyD } \\
\text { (Hd) }\end{array}$ & $\begin{array}{l}\text { HeavyC } \\
\text { (Hc) }\end{array}$ & $\begin{array}{l}\text { Upper } \\
\text { Medium } \\
\text { (UM) }\end{array}$ & $\begin{array}{l}\text { Lower } \\
\text { Medium } \\
\text { (LM) }\end{array}$ & $\begin{array}{l}\text { SmallC } \\
\text { (Sc) }\end{array}$ & $\begin{array}{l}\text { SmallD } \\
\text { (Sd) }\end{array}$ & $\begin{array}{l}\text { Light } \\
\text { (L) }\end{array}$ \\
\hline & Super (J) & 1.78 & 2.34 & 2.67 & 3.07 & 3.11 & 3.21 & 3.65 & 4.53 \\
\hline & $\begin{array}{l}\text { Heavy } \\
\text { (H) }\end{array}$ & 1.78 & 1.56 & 1.78 & 2.19 & 2.22 & 2.75 & 3.13 & 3.96 \\
\hline & $\begin{array}{l}\text { Upper } \\
\text { Medium } \\
\text { (UM) }\end{array}$ & 1.11 & 0.97 & 1.11 & 1.31 & 1.78 & 1.83 & 2.09 & 3.40 \\
\hline & $\begin{array}{l}\text { Lower } \\
\text { medium } \\
(\mathrm{LM})\end{array}$ & 1.11 & 0.97 & 1.11 & 1.09 & 1.11 & 1.37 & 1.57 & 2.83 \\
\hline & Small (S) & 1.11 & 0.97 & 1.11 & 1.09 & 1.11 & 1.37 & 1.57 & 2.26 \\
\hline & Light (L) & 1.11 & 0.97 & 1.11 & 1.09 & 1.11 & 1.15 & 1.30 & 1.42 \\
\hline
\end{tabular}

Source: ??? 
All the aircraft in the simulation are then also assigned a runway occupation time (see Section 3.4). In this exercise, arrivals are simulated before departures as inbound aircraft have priority.

The simulation starts at 0 minutes and it is assumed the first arrival crosses the runway threshold at this time. The next aircraft is assumed to be following the first at minimum separation. Thus if the required separation between the aircraft is 1.11 minutes, the next aircraft is 1.11 minutes away from crossing runway threshold when the first aircraft is at the threshold. Table 3 provides illustrates simulated aircraft arrivals and shows how separation distances determine the time in the simulation at which they enter the runway. The runway occupancy times for arriving aircraft are required to calculate departures. The process continues until the simulation reaches 60 minutes at which point the arrivals are stopped and counted.

Table 3 - Example of arrival simulations at Heathrow

\begin{tabular}{|r|r|l|r|l|l|l|r|}
\hline Aircraft & Random & $\begin{array}{l}\text { Aircraft } \\
\text { category }\end{array}$ & $\begin{array}{l}\text { Separation } \\
\text { (mins) }\end{array}$ & $\begin{array}{l}\text { Runway } \\
\text { occupation } \\
\text { time } \\
\text { (mins) }\end{array}$ & $\begin{array}{l}\text { Enter } \\
\text { Runway } \\
\text { (mins) }\end{array}$ & $\begin{array}{l}\text { Exit } \\
\text { Runway } \\
\text { (mins) }\end{array}$ & $\begin{array}{l}\text { Unoccupied } \\
\text { Duration } \\
\text { (mins) }\end{array}$ \\
\hline $\mathbf{1}$ & 0.666653 & Hd & 0 & 0.83 & 0 & 0.83 & 1.39 \\
\hline $\mathbf{2}$ & 0.568444 & LM & 2.22 & 0.67 & 2.22 & 2.89 & 0.44 \\
\hline $\mathbf{3}$ & 0.43141 & LM & 1.11 & 0.67 & 3.33 & 4.00 & 0.44 \\
\hline $\mathbf{4}$ & 0.307736 & LM & 1.11 & 0.67 & 4.44 & 5.11 & 0.44 \\
\hline $\mathbf{5}$ & 0.597959 & Hc & 1.11 & 0.67 & 5.55 & 6.22 & 0.95 \\
\hline $\mathbf{6}$ & 0.661426 & Hc & 1.11 & 0.83 & 7.17 & 8.00 & 1.39 \\
\hline
\end{tabular}

Simulating departures similarly requires aircraft category, separation time and runway occupancy time to be calculated. Suitable gaps must then be found in the sequence of 
arriving traffic in which to slot in departures. A departure requires both the minimum separation time from the preceding departure and a gap to the next arrival that is greater than its own runway occupation time (Table 4).

Table 4 - Example of departure simulations at Heathrow (using arrivals data presented in Table 3).

\begin{tabular}{|r|l|l|r|r|r|r|}
\hline Observation & Random & $\begin{array}{l}\text { A/c } \\
\text { category }\end{array}$ & \multicolumn{1}{|l|}{ Separation } & \multicolumn{1}{l|}{$\begin{array}{l}\text { Runway } \\
\text { occupation }\end{array}$} & $\begin{array}{l}\text { Enter } \\
\text { Runway }\end{array}$ & \multicolumn{1}{l|}{$\begin{array}{l}\text { Runit } \\
\text { Runway }\end{array}$} \\
\hline $\mathbf{1}$ & 0.313926 & LM & n/a & 0.83 & 0.83 & 1.66 \\
\hline $\mathbf{2}$ & 0.247403 & Hc & 1.33 & 0.83 & 6.22 & 7.05 \\
\hline $\mathbf{3}$ & 0.570501 & LM & 2 & 0.83 & 8.22 & 9.05 \\
\hline $\mathbf{4}$ & 0.453592 & LM & 1.33 & 0.83 & & \\
\hline $\mathbf{5}$ & 0.631647 & UM & 1.33 & 0.83 & & \\
\hline $\mathbf{6}$ & 0.471327 & LM & 1.33 & 0.83 & & \\
\hline
\end{tabular}

This process is repeated for 60 minutes. The simulation is then stopped and the departures are counted. Any aircraft that has begun its take-off roll but which has not left the runway within these 60 minutes is not counted. The arrivals and departures are then added together to give an overall figure of theoretical maximum peak hour capacity. The only exceptions to this are the simulations at Heathrow under segregated mode operations (in which one runway is used for arrivals the other for departures) and in cases where runway layout dictates that runway crossings are simulated.

\section{Data}


The simulations employed four main variables.

\subsection{Aircraft Separation minima}

All aircraft create wake turbulence which can pose a danger to other air traffic. The International Civil Aviation Organisation (ICAO) assign commercial aircraft to wake categories according to the strength of the vortices they produce and publish minimum separation distance guidelines. These guidelines have been modified by the UK’s Civil Aviation Authority (CAA) to include extra categories. The Super (J) category was specifically added for A380. The Medium (M) category is split into subcategories for arrivals in the UK. The Lower Medium (LM) category allows common aircraft types such as the B737 and A320 to be treated separately from higher vortexproducing aircraft in the Upper Medium (UM) category. These categories are based on the manufacturer's certified Maximum Take-Off Weight (MTOW) of each aircraft (Table 5).

Table 5 - Aircraft wake vortex separation categories (NATS, 2010).

\begin{tabular}{|l|l|l|l|}
\hline Category & $\begin{array}{l}\text { UK Arrivals (MTOW, } \\
\text { kg) }\end{array}$ & $\begin{array}{l}\text { UK Departures } \\
\text { (MTOW, kg) }\end{array}$ & Example Aircraft \\
\hline Super (J) & A380 only & A380 only & A380 only \\
\hline Heavy (H) & $>162000$ & $>162000$ & B747, B767, A340 \\
\hline Medium (M) & N/A & $\begin{array}{l}>40000 ~ \&< \\
162000\end{array}$ & B737, A320, B757 \\
\hline $\begin{array}{l}\text { Upper Medium } \\
\text { (UM) }\end{array}$ & $>104000 \&<162000$ & N/A & B757 \\
\hline $\begin{array}{l}\text { Lower Medium } \\
\text { (LM) }\end{array}$ & $>40000 \&<104000$ & N/A & B737, A320 \\
\hline Small (S) & $>17000 \&<40000$ & $>17000 \&<40000$ & $\begin{array}{l}\text { DHC-8, ATR72, } \\
\text { E145 }\end{array}$ \\
\hline Light (L) & $<17000$ & & Do328, J41 \\
\hline
\end{tabular}


Table 6 shows the CAA wake vortex separation for aircraft on final approach. These separation minima apply to all the London airports used in this investigation and cannot be breached. However, as the simulations work in time rather than distance, aircraft speeds on final approach are required.

Table 6 - CAA Approach separation minima in nautical miles (NATS, 2010)

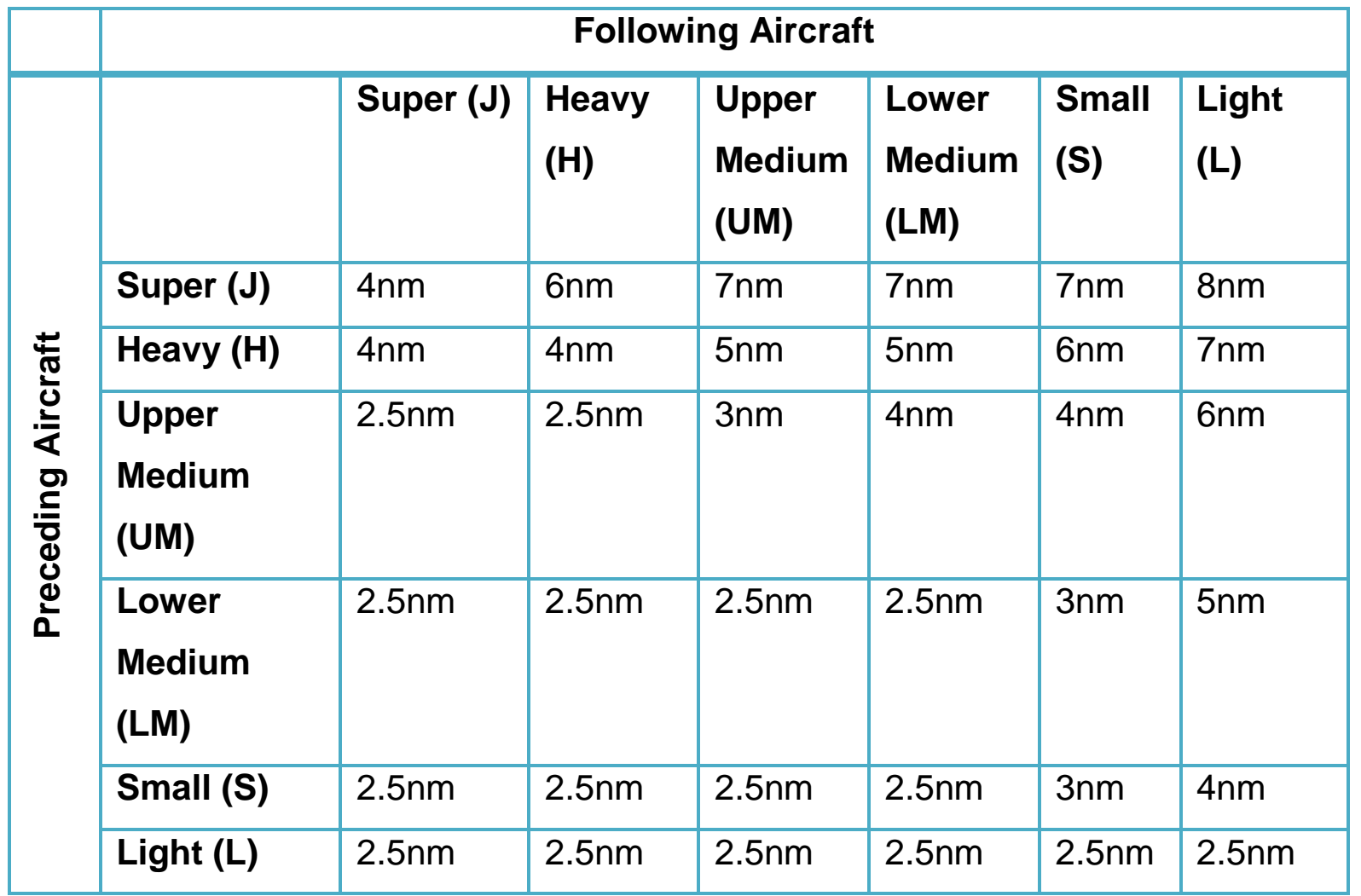

Table 7 shows the CAA wake vortex separation for departing aircraft. These figures are presented in time (minutes), rather than distance, to simplify air traffic control sequencing.

Table 7 - Departure wake vortex separation, in minutes (NATS, 2010)

\begin{tabular}{|c|c|c|c|c|c|c|}
\hline & \multicolumn{6}{|c|}{ Following aircraft } \\
\hline 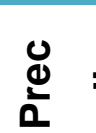 & ? & Super (J) & $\begin{array}{l}\text { Heavy } \\
\text { (H) }\end{array}$ & $\begin{array}{l}\text { Medium } \\
\text { (M) }\end{array}$ & $\begin{array}{l}\text { Small } \\
\text { (S) }\end{array}$ & Light(L) \\
\hline
\end{tabular}




\begin{tabular}{|l|l|l|l|l|l|l|}
\hline Super (J) & 2 & 2 & 3 & 3 & 3 \\
\hline Heavy (H) & 1.333 & 1.333 & 2 & 2 & 2 \\
\hline Medium (M) & 1.333 & 1.333 & 1.333 & 1.333 & 2 \\
\hline Small (S) & 1.333 & 1.333 & 1.333 & 1.333 & 2 \\
\hline Light (L) & 1.333 & 1.333 & 1.333 & 1.333 & 1.333 \\
\hline
\end{tabular}

A standard minimum separation of 1.33 (1 minute and 20 seconds) is given where separation is not required for wake turbulence reasons.

\subsection{Aircraft Speeds}

Aircraft speeds are needed to convert arrival separation distances into time. However, this task is not straightforward. An aircraft's final approach speed depends on a number of factors including weight, meteorological conditions and local operating requirements. Each aircraft type also has a different approach speed on account of each airframe’s aerodynamic stalling speed. In order to convert wake turbulence categories into average approach speeds, a number of assumptions needed to be made. These included identifying the approach speeds of specific aircraft within a wake turbulence category and then calculating an average speed.

Although most of the aircraft within individual categories have very consistent approach speeds, aircraft in the Heavy and Small categories showed considerable variation. For example, in the Heavy category, the B747 has an approach speed of around 154kts while the smaller B767 has an approach speed closer to 135kts. Similarly, the small aircraft category includes both jets and turboprops which have vastly different approach speeds. As a result, the Heavy and Small categories have been further subdivided into HeavyD, HeavyC, SmallC and SmallB (Table 8). 
Table 8 - Aircraft approach speeds and wake turbulence categories

\begin{tabular}{|l|l|l|}
\hline $\begin{array}{l}\text { New Wake } \\
\text { turbulence } \\
\text { category }\end{array}$ & $\begin{array}{l}\text { Approach } \\
\text { speed } \\
\text { category }\end{array}$ & $\begin{array}{l}\text { Approximate } \\
\text { approach } \\
\text { speed }\end{array}$ \\
\hline Super (J) & C & $135 \mathrm{kts}$ \\
\hline HeavyD (Hd) & D & $154 \mathrm{kts}$ \\
\hline HeavyC (Hc) & C & $135 \mathrm{kts}$ \\
\hline $\begin{array}{l}\text { Upper Medium } \\
\text { (UM) }\end{array}$ & C & $137 \mathrm{kts}$ \\
\hline $\begin{array}{l}\text { Lower Medium } \\
\text { (LM) }\end{array}$ & C & $135 \mathrm{kts}$ \\
\hline SmallC (Sc) & C & $131 \mathrm{kts}$ \\
\hline SmallB (Sb) & B & $106 \mathrm{kts}$ \\
\hline Light & B & $106 \mathrm{kts}$ \\
\hline
\end{tabular}

This process enables further refinements to be made to the simulation (Table 9).

Table 9 - Separation times for aircraft wake turbulence categories, in minutes

\begin{tabular}{|c|c|c|c|c|c|c|c|c|c|}
\hline & & & & Follo & ing Airc & aft & & & \\
\hline & & $\begin{array}{l}\text { Super } \\
\text { (J) }\end{array}$ & $\begin{array}{l}\text { HeavyD } \\
\text { (Hd) }\end{array}$ & $\begin{array}{l}\text { HeavyC } \\
(\mathrm{Hc})\end{array}$ & $\begin{array}{l}\text { Upper } \\
\text { Medium } \\
\text { (UM) }\end{array}$ & $\begin{array}{l}\text { Lower } \\
\text { Medium } \\
\text { (LM) }\end{array}$ & $\begin{array}{l}\text { SmallC } \\
\text { (Sc) }\end{array}$ & $\begin{array}{l}\text { SmallD } \\
\text { (Sd) }\end{array}$ & $\begin{array}{l}\text { Light } \\
\text { (L) }\end{array}$ \\
\hline$\frac{ \pm}{\sigma}$ & $\begin{array}{l}\text { Super } \\
\text { (J) }\end{array}$ & 1.78 & 2.34 & 2.67 & 3.07 & 3.11 & 3.21 & 3.65 & 4.53 \\
\hline 은 & $\begin{array}{l}\text { Heavy } \\
\text { (H) }\end{array}$ & 1.78 & 1.56 & 1.78 & 2.19 & 2.22 & 2.75 & 3.13 & 3.96 \\
\hline 응 & $\begin{array}{l}\text { Upper } \\
\text { Medium } \\
\text { (UM) }\end{array}$ & 1.11 & 0.97 & 1.11 & 1.31 & 1.78 & 1.83 & 2.09 & 3.40 \\
\hline & $\begin{array}{l}\text { Lower } \\
\text { medium } \\
\text { (LM) }\end{array}$ & 1.11 & 0.97 & 1.11 & 1.09 & 1.11 & 1.37 & 1.57 & 2.83 \\
\hline & Small & 1.11 & 0.97 & 1.11 & 1.09 & 1.11 & 1.37 & 1.57 & 2.26 \\
\hline
\end{tabular}




\begin{tabular}{|l|l|l|l|l|l|l|l|l|}
\hline $\mathbf{( S )}$ & & & & & & & & \\
\hline Light (L) & 1.11 & 0.97 & 1.11 & 1.09 & 1.11 & 1.15 & 1.30 & 1.42 \\
\hline
\end{tabular}

\subsection{Traffic Mix}

Information on the average traffic mix of aircraft currently using Heathrow, Gatwick and Stansted airports was obtained from Heathrow Airport (2010a) and Airport Coordination Ltd (2010). Each aircraft type was cross-referenced with an aircraft database to establish the manufacturer's MTOW and assign it to a wake turbulence category. These were then collated to produce probabilities of each category at each airport (Table 10).

Table 10 - Traffic as percentages of each wake vortex category.

\begin{tabular}{|l|l|l|l|}
\hline Category & Heathrow & Gatwick & Stansted \\
\hline Super (J) & $0.7 \%$ & $0 \%$ & $0 \%$ \\
\hline Heavy (H) & $34.4 \%$ & $9.35 \%$ & $4.3 \%$ \\
\hline $\begin{array}{l}\text { Upper } \\
\text { Medium (UM) }\end{array}$ & $2.3 \%$ & $4 \%$ & $0.6 \%$ \\
\hline $\begin{array}{l}\text { Lower } \\
\text { Medium (LM) }\end{array}$ & $60.4 \%$ & $75.5 \%$ & $91.9 \%$ \\
\hline Small (S) & $2.2 \%$ & $11 \%$ & $2.6 \%$ \\
\hline Light (L) & $0 \%$ & $0.15 \%$ & $0.6 \%$ \\
\hline
\end{tabular}

Owing to the widespread entry into service of the Airbus A380, it is believed the percentage of A380 flights will increase threefold by 2020 (Heathrow Airport, 2012). It is likely some of these A380s will replace flights by Heavy B747 aircraft. With this in mind, we assume that 'Super' category aircraft at Heathrow will account for $2.8 \%$ of total movements and Heavies $32.3 \%$ in the future. 


\subsection{Runway occupancy time}

The simulations also require information about the average length of time arriving and departing aircraft spend on the runway. For arriving aircraft this means the time from crossing the threshold to vacating via a runway exit. For departing aircraft, this is defined as the moment they enter the runway to the point they become airborne.

An aircraft's runway occupancy time depends on numerous variables including size, weight, acceleration/deceleration and individual flightcrew. For this investigation, the runway occupancy times derived from ICAO rules and used by Pitfield and Jerrard (1999) were adopted. Consequently, the average occupancy time for a departing aircraft is 50 seconds. For arriving aircraft they are: 30 seconds for 'light' category aircraft , 40 seconds for 'Small’, ‘Lower Medium’ and ‘Upper Medium’ category aircraft, and 50 seconds for 'Heavy' and 'Super' aircraft.

\section{Simulating current capacity at London airports}

Current peak hour capacity simulations were performed for London's three busiest passenger airports: Heathrow, Gatwick and Stansted.

\subsection{Heathrow}

Heathrow airport is surrounded by densely populated urban areas and has two independent parallel runways, 27L/09R and 27R/09L. These runways have historically been used in segregated mode to give local residents some relief from aircraft noise. Owing to prevailing wind directions and the frequency of their use, the “27” runways are used in these simulations. Both runways feature high-speed taxiway turnoffs which facilitate rapid access and egress. Our simulation assumes that the arrival runway is $27 \mathrm{~L}$ and that departures can use both runways. Owing to a lack of 
available slots and the number of long-haul flights at the airport, Heathrow's traffic mix is dominated by 'Heavy' aircraft.

Table 11 - Heathrow "current situation" simulations.

\begin{tabular}{|r|r|r|r|r|r|}
\hline Simulation & \multicolumn{1}{l|l}{$\begin{array}{l}\text { 27L } \\
\text { Arrivals }\end{array}$} & $\begin{array}{l}\text { 27R } \\
\text { Departures }\end{array}$ & $\begin{array}{l}\text { 27R } \\
\text { Arrivals } \\
\text { Departures }\end{array}$ & \multicolumn{1}{l|}{ Total } \\
\hline $\mathbf{1}$ & 42 & 13 & 0 & 40 & 95 \\
\hline $\mathbf{2}$ & 40 & 15 & 0 & 40 & 95 \\
\hline $\mathbf{3}$ & 44 & 12 & 0 & 38 & 94 \\
\hline $\mathbf{4}$ & 41 & 15 & 0 & 40 & 96 \\
\hline $\mathbf{5}$ & 41 & 14 & 0 & 40 & 95 \\
\hline $\mathbf{6}$ & 42 & 12 & 0 & 41 & 95 \\
\hline $\mathbf{7}$ & 41 & 14 & 0 & 40 & 95 \\
\hline $\mathbf{8}$ & 42 & 11 & 0 & 42 & 95 \\
\hline $\mathbf{9}$ & 38 & 18 & 0 & 40 & 96 \\
\hline $\mathbf{1 0}$ & 41 & 13 & 0 & 41 & 95 \\
\hline Average & 41.2 & 13.7 & 0 & 40.2 & 95.1 \\
\hline
\end{tabular}

Table 11 shows that Heathrow's current peak hour capacity is around 95 movements. This is close to the official figure of 96 (Heathrow Airport, 2010b) and shows that the assumptions in the simulation are appropriate and accurate.

\subsection{Gatwick}

Gatwick Airport is the busiest single runway airport in the World. Although the facility has two runways, they are too close together to be operated simultaneously and usually only the longer 26L/08R is active. Our simulation assumes a singlerunway operation. Owing to the dominance of B737 and A320 family aircraft that are used by the low cost and charter operators, $75 \%$ of aircraft at Gatwick are in the Lower Medium wake category. The results of the peak hour simulations at Gatwick 
appear in Table 12. They are slightly higher than the official declared hourly capacity of 53 (ACL, 2012a).

Table 12 - Gatwick "Current situation" simulations.

\begin{tabular}{|r|r|r|r|}
\hline Simulation & Arrivals & Departures & \multicolumn{1}{l|}{ Total } \\
\hline $\mathbf{1}$ & 48 & 12 & 60 \\
\hline $\mathbf{2}$ & 49 & 6 & 55 \\
\hline $\mathbf{3}$ & 48 & 10 & 58 \\
\hline $\mathbf{4}$ & 47 & 10 & 57 \\
\hline $\mathbf{5}$ & 46 & 11 & 57 \\
\hline $\mathbf{6}$ & 48 & 11 & 59 \\
\hline $\mathbf{7}$ & 46 & 10 & 56 \\
\hline $\mathbf{8}$ & 47 & 9 & 56 \\
\hline $\mathbf{9}$ & 47 & 9 & 56 \\
\hline $\mathbf{1 0}$ & 44 & 14 & 58 \\
\hline Average & 47 & 10.2 & 57.2 \\
\hline
\end{tabular}

\subsection{Stansted}

Stansted has a single runway and a single terminal. Like Gatwick, Stansted's traffic mix is dominated by Lower Medium category aircraft on account of easyJet and Ryanair's use of A319 and B737 aircraft respectively. The simulations indicate that Stansted can accommodate 54 aircraft per hour, four more than the official decalred capacity (ACL, 2012b).

Table 13 - Stansted "Current situation" simulations

\begin{tabular}{|r|r|r|r|}
\hline Simulation & Arrivals & Departures & Total \\
\hline $\mathbf{1}$ & 54 & 0 & 54 \\
\hline $\mathbf{2}$ & 53 & 2 & 55 \\
\hline $\mathbf{3}$ & 51 & 4 & 55 \\
\hline
\end{tabular}




\begin{tabular}{|r|r|r|r|}
\hline $\mathbf{4}$ & 52 & 2 & 54 \\
\hline $\mathbf{5}$ & 50 & 5 & 55 \\
\hline $\mathbf{6}$ & 50 & 5 & 55 \\
\hline $\mathbf{7}$ & 51 & 4 & 55 \\
\hline $\mathbf{8}$ & 52 & 3 & 55 \\
\hline $\mathbf{9}$ & 50 & 4 & 54 \\
\hline $\mathbf{1 0}$ & 51 & 3 & 54 \\
\hline Average & 51.4 & 3.2 & 54.6 \\
\hline
\end{tabular}

3.4 Current combined capacity of Heathrow, Gatwick and Stansted

Table 15 shows the combined capacity of the three main London airports that were simulated in this section. The estimated total peak hour capacity is just under 263 movements. This is around 31 movements (11.7\%) higher than the sum of the airports' official declared capacities and mean that the simulations yield results 4-5\% higher than the declared capacity.

Table 14 - Total hourly capacity for London airports in current situation

\begin{tabular}{|l|r|r|r|r|r|}
\hline Airport & Arrivals & Departures & \multicolumn{2}{l|}{ Total } \\
Movements & $\begin{array}{l}\text { Airport's } \\
\text { declared } \\
\text { capacity }\end{array}$ & Difference \\
\hline Heathrow & 41.2 & 53.9 & 95.1 & 96 & -0.9 \\
\hline Gatwick & 47.0 & 10.2 & 57.2 & 53 & +4.2 \\
\hline Stansted & 51.4 & 3.2 & 54.6 & 50 & +4.6 \\
\hline All & $\mathrm{XX}$ & $\mathrm{XX}$ & $\mathrm{XX}$ & $\mathrm{XX}$ & $\mathrm{XX}$ \\
London & & & & & \\
Airports & & & & & \\
\hline
\end{tabular}




\section{Monte-Carlo Simulations of proposed capacity enhancements}

This section reports on the findings of capacity simulations for five proposed capacity enhancements in order to compare and contrast the capacity effects of the individual options against the current baseline capacity figures. The results of the Monte Carol simulations into the effects of a new hub airport in the Thames Estuary will be presented first. This will be followed by simulations into the effects of new runways at Heathrow, Gatwick and Stansted and the abolition of segregated mode operations at Heathrow.

\subsection{New hub airport}

A number of different proposals and locations for a new four-runway airport to the east of London in the Thames Estuary have been proposed by construction companies and developers. These designs typically feature four parallel runways and a central terminal area and would result in the closure of Heathrow (BBC 2012b). For the simulations it is assumed that the new facility will have a similar traffic mix to Heathrow, albeit with a slightly higher proportion of smaller aircraft owing to the availability of more slots (see Table 16).

Table 16 - Traffic mix at Heathrow and (assumed) traffic mix at a new hub airport

\begin{tabular}{|l|l|l|}
\hline Aircraft category & Percentage at Heathrow & $\begin{array}{l}\text { Percentage at new hub } \\
\text { airport }\end{array}$ \\
\hline Super (J) & $2.8 \%$ & $2.8 \%$ \\
\hline Heavy d (Hd) & $16.15 \%$ & $16.15 \%$ \\
\hline Heavy (Hc) & $16.15 \%$ & $16.15 \%$ \\
\hline Upper Medium (UM) & $2.3 \%$ & $2.3 \%$ \\
\hline Lower Medium (LM) & $60.4 \%$ & $50.4 \%$ \\
\hline Small c (Sc) & $2.0 \%$ & $7.0 \%$ \\
\hline
\end{tabular}




\begin{tabular}{|l|l|l|}
\hline Small b (Sb) & $0.2 \%$ & $5.2 \%$ \\
\hline Light (L) & $0 \%$ & $0 \%$ \\
\hline
\end{tabular}

Table 17 shows the output of the simulations for the Thames estuary airport. The maximum capacity of the airport is estimated at around 217 movements per hour, 119 more than at Heathrow.

Table 17 - Simulations for Thames Estuary airport

\begin{tabular}{|r|r|r|r|r|r|r|r|r|r|}
\hline Simulation & $\begin{array}{l}\text { R1 } \\
\text { Arrivals }\end{array}$ & $\begin{array}{l}\text { R1 } \\
\text { Dep's }\end{array}$ & $\begin{array}{l}\text { R2 } \\
\text { Arrivals }\end{array}$ & $\begin{array}{l}\text { R2 } \\
\text { Dep's }\end{array}$ & $\begin{array}{l}\text { R3 } \\
\text { Arrivals }\end{array}$ & $\begin{array}{l}\text { R3 } \\
\text { Dep's }\end{array}$ & $\begin{array}{l}\text { R4 } \\
\text { Arrivals }\end{array}$ & $\begin{array}{l}\text { R4 } \\
\text { Dep's }\end{array}$ & Total \\
\hline $\mathbf{1}$ & 39 & 16 & 40 & 15 & 41 & 14 & 39 & 14 & 218 \\
\hline $\mathbf{2}$ & 37 & 15 & 40 & 13 & 40 & 15 & 41 & 15 & 216 \\
\hline $\mathbf{3}$ & 42 & 11 & 41 & 14 & 38 & 14 & 40 & 13 & 213 \\
\hline $\mathbf{4}$ & 38 & 15 & 40 & 13 & 39 & 18 & 42 & 13 & 218 \\
\hline $\mathbf{5}$ & 37 & 18 & 40 & 14 & 37 & 16 & 39 & 16 & 217 \\
\hline $\mathbf{6}$ & 38 & 18 & 39 & 15 & 38 & 16 & 40 & 13 & 217 \\
\hline $\mathbf{7}$ & 37 & 18 & 38 & 14 & 39 & 15 & 43 & 10 & 214 \\
\hline $\mathbf{8}$ & 41 & 12 & 45 & 10 & 41 & 13 & 40 & 16 & 218 \\
\hline $\mathbf{9}$ & 39 & 16 & 38 & 17 & 38 & 16 & 41 & 12 & 217 \\
\hline $\mathbf{1 0}$ & 38 & 18 & 41 & 13 & 38 & 17 & 41 & 13 & 219 \\
\hline Average & 38.6 & 15.7 & 40.2 & 13.8 & 38.9 & 15.4 & 40.6 & 13.5 & $\mathbf{2 1 6 . 7}$ \\
\hline
\end{tabular}

The simulations show that the construction of a new hub airport will have a dramatic effect, potentially increasing London's airport capacity by $46 \%$. Although the construction of a new hub airport has been advocated by both politicians, developers and some sections of the aviation community, concerns about cost, environmental impact and airspace conflict with Amsterdam Schiphol means that alternative proposals to expand Heathrow are also being considered.

\section{2i Heathrow $3^{\text {rd }}$ Runway}

One initial option for enhancing Heathrow's capacity involved constructing a third runway to the north of the existing airfield. The runway would be built far enough to the north to allow for the simultaneous operation of all three runways. This would, 
however, oblige some aircraft to cross the active centre runway when transiting between the northern-most runway and the central terminal area. In the simulation, we assume all aircraft using the new third runway will use the proposed new sixth terminal (thereby removing the need to cross any active runways) and that the new runway would handle a similar traffic mix. The existing segregated mode operation will be retained, although it is assumed arrivals can land on the new runway at any time.

Table 15 - Simulations for Heathrow with third runway

\begin{tabular}{|c|c|c|c|c|c|c|c|}
\hline Simulation & $\begin{array}{l}27 \mathrm{~L} \\
\text { Arrivals }\end{array}$ & $\begin{array}{l}27 \mathrm{~L} \\
\text { Departures }\end{array}$ & $\begin{array}{l}\text { 27R } \\
\text { Arrivals }\end{array}$ & $\begin{array}{l}\text { 27R } \\
\text { Departures }\end{array}$ & $\begin{array}{l}3^{\text {rd }} \text { runway } \\
\text { Arrivals }\end{array}$ & $\begin{array}{l}3^{\text {rd }} \text { runway } \\
\text { Departures }\end{array}$ & Total \\
\hline 1 & 42 & 13 & 0 & 40 & 44 & 11 & 150 \\
\hline 2 & 40 & 15 & 0 & 40 & 41 & 14 & 150 \\
\hline 3 & 44 & 12 & 0 & 38 & 40 & 14 & 148 \\
\hline 4 & 41 & 15 & 0 & 40 & 42 & 13 & 151 \\
\hline 5 & 41 & 14 & 0 & 40 & 41 & 13 & 149 \\
\hline 6 & 42 & 12 & 0 & 41 & 41 & 15 & 151 \\
\hline 7 & 41 & 14 & 0 & 40 & 37 & 19 & 151 \\
\hline 8 & 42 & 11 & 0 & 42 & 45 & 9 & 149 \\
\hline 9 & 38 & 18 & 0 & 40 & 44 & 11 & 151 \\
\hline 10 & 41 & 13 & 0 & 41 & 43 & 11 & 149 \\
\hline Average & 41.2 & 13.7 & 0 & 40.2 & 41.8 & 13 & 149.9 \\
\hline
\end{tabular}

Table 18 shows the simulations for the two current runways and also the simulations for the third runway. The new total peak hour capacity is just under 150 movements. Compared to the current situation, this option represents an increase in total capacity of $57.6 \%$ and an overall increase in the capacity of London airports of $20.9 \%$ (Table 19). 
Table 19 - Comparison between Heathrow Third Runway and Current Situation simulations

\begin{tabular}{|l|l|l|l|l|}
\hline & $\begin{array}{l}\text { Current } \\
\text { situation } \\
\text { capacity }\end{array}$ & $\begin{array}{l}\text { Heathrow } \\
\text { Third Runway } \\
\text { capacity }\end{array}$ & Difference & $\begin{array}{l}\text { Percentage } \\
\text { Change }\end{array}$ \\
\hline Heathrow & 95.1 & 149.9 & 54.8 & $57.6 \%$ \\
\hline $\begin{array}{l}\text { All London } \\
\text { airports }\end{array}$ & 262.6 & 317.4 & 54.8 & $20.9 \%$ \\
\hline
\end{tabular}

\section{2ii Heathrow Westward Expansion}

Another option that has been proposed is to expand Heathrow westwards by building two new parallel runways to the west of the existing pair along the same alignment (Leunig, 2012). The main suggested advantages of this scheme are that it would permit a significant increase in capacity, would not require the destruction of local villages and would reduce the number of people adversely affected by aircraft noise. This is because the approach path would be moved a few kilometres to the west meaning aircraft should be significantly higher (and quieter) to the east of the airport. The simulations show that this layout can accommodate around 164 peak hour movements (Table 20).

Table 20 - Output of simulations for Heathrow westward expansion

\begin{tabular}{|r|l|r|r|r|r|}
\hline Simulation & $\begin{array}{l}\text { Runway \#1 } \\
\text { "Wide-Body" } \\
\text { Arrivals }\end{array}$ & $\begin{array}{l}\text { Runway \#2 } \\
\text { Departures }\end{array}$ & $\begin{array}{l}\text { Runway \#3 } \\
\text { Departures }\end{array}$ & $\begin{array}{l}\text { Runway \#4 } \\
\text { "Narrow- } \\
\text { Body } \\
\text { Arrivals }\end{array}$ & $\begin{array}{l}\text { Total (All } \\
\text { runways) }\end{array}$ \\
\hline $\mathbf{1}$ & 34 & 38 & 40 & 51 & 163 \\
\hline $\mathbf{2}$ & 36 & 40 & 41 & 48 & 165 \\
\hline $\mathbf{3}$ & 34 & 39 & 40 & 52 & 165 \\
\hline $\mathbf{4}$ & 37 & 40 & 38 & 50 & 165 \\
\hline $\mathbf{5}$ & 37 & 38 & 41 & 49 & 165 \\
\hline $\mathbf{6}$ & 36 & 40 & 39 & 50 & 165 \\
\hline $\mathbf{7}$ & 36 & 38 & 41 & 50 & 165 \\
\hline $\mathbf{8}$ & 35 & 37 & 40 & 50 & 162 \\
\hline
\end{tabular}




\begin{tabular}{|r|r|r|r|r|r|}
\hline $\mathbf{9}$ & 36 & 38 & 41 & 51 & 166 \\
\hline 10 & 36 & 39 & 40 & 48 & 163 \\
\hline Average & 35.7 & 38.7 & 40.1 & 49.9 & 164.4 \\
\hline
\end{tabular}

Table 21 shows how the outputs of the simulations compare with the two most proposals already simulated; the plan to build a third northern runway at Heathrow and the plan to construct a new hub airport in the Thames Estuary.

Table 21 - Comparing the results of the westward expansion simulations with similar proposals

\begin{tabular}{|l|l|l|l|l|l|}
\hline $\begin{array}{l}\text { Expansion } \\
\text { Proposal }\end{array}$ & $\begin{array}{l}\text { London } \\
\text { "Current } \\
\text { Situation" } \\
\text { Capacity }\end{array}$ & $\begin{array}{l}\text { Capacity } \\
\text { with } \\
\text { expansion } \\
\text { proposal }\end{array}$ & Difference & $\begin{array}{l}\text { Percentage } \\
\text { Change }\end{array}$ & $\begin{array}{l}\text { Estimated } \\
\text { Cost }\end{array}$ \\
\hline $\begin{array}{l}\text { Heathrow } \\
\text { Third } \\
\text { Runway }\end{array}$ & 262.6 & 317.2 & +54.6 & $+20.79 \%$ & $£ 10 \mathrm{bn}$ \\
\hline $\begin{array}{l}\text { Thames } \\
\text { Estuary } \\
\text { Airport } \\
\text { (replace } \\
\text { LHR) }\end{array}$ & 262.6 & 384 & +121.4 & $+46.23 \%$ & $£ 50 \mathrm{bn}$ \\
\hline $\begin{array}{l}\text { Heathrow } \\
\text { Westward } \\
\text { Expansion }\end{array}$ & 262.6 & 332 & +69.4 & $+26.43 \%$ & $£ 10 \mathrm{bn}$ \\
\hline
\end{tabular}

The westward expansion proposal increases the total runway capacity of London by a little over 26\%. However, this compares unfavourably with the replacement of Heathrow with a new hub in the Thames Estuary which would provide nearly double the capacity, even though the number of runways is exactly the same. Indeed, the westward expansion only provides around a 5\% improvement on the capacity a third runway at Heathrow would provide.

\section{$4.22^{\text {nd }}$ runway at Gatwick}

Although a local agreement prevents the construction of a second runway at Gatwick before 2019, a second runway has been proposed as a way of alleviating some of the 
existing capacity constraints at London airports. Under current plans, the new runway would be located to the south of the existing one and oblige aircraft to cross the active northern runway to access and leave the terminal areas. Table 22 shows that the new runway roughly doubles the airport's capacity. Interestingly, it also suggests that Gatwick with two runways would be able to handle 9 extra movements per hour than Heathrow's two runways (with no runway use restrictions) and nearly 5 more per hour than Stansted with two runways (see Section 4.4).

Table 22 - Simulations for Gatwick Airport with the new runway

\begin{tabular}{|l|l|l|l|l|l|l|}
\hline Simulation & $\begin{array}{l}\mathbf{1}^{\text {st }} \text { Runway } \\
\text { Arrivals }\end{array}$ & $\begin{array}{l}\mathbf{1}^{\text {st }} \text { Runway } \\
\text { Departures }\end{array}$ & $\begin{array}{l}\mathbf{2}^{\text {nd }} \\
\text { Runway } \\
\text { Arrivals }\end{array}$ & $\begin{array}{l}\mathbf{2}^{\text {nd }} \text { Runway } \\
\text { Departures }\end{array}$ & $\begin{array}{l}\text { Total } \\
\text { Movements }\end{array}$ & $\begin{array}{l}\text { Average } \\
\text { runway } \\
\text { crossing } \\
\text { delay }\end{array}$ \\
\hline $\mathbf{1}$ & 48 & 12 & 49 & 9 & 118 & 1.45 mins \\
\hline $\mathbf{2}$ & 49 & 6 & 46 & 9 & 110 & 0.36 mins \\
\hline $\mathbf{3}$ & 48 & 10 & 47 & 11 & 116 & 0.70 mins \\
\hline $\mathbf{4}$ & 47 & 10 & 47 & 9 & 113 & 0.46 mins \\
\hline $\mathbf{5}$ & 46 & 11 & 49 & 9 & 115 & 0.64 mins \\
\hline $\mathbf{6}$ & 48 & 11 & 50 & 7 & 116 & 0.74 mins \\
\hline $\mathbf{7}$ & 46 & 10 & 44 & 12 & 112 & 0.40 mins \\
\hline $\mathbf{8}$ & 47 & 9 & 49 & 9 & 114 & 0.54 mins \\
\hline $\mathbf{9}$ & 47 & 9 & 43 & 14 & 113 & 0.50 mins \\
\hline $\mathbf{1 0}$ & 44 & 14 & 47 & 9 & 114 & 0.57 mins \\
\hline Average & 47 & 10.2 & 47.1 & 9.8 & $\mathbf{1 1 4 . 1}$ & $\mathbf{0 . 6 4}$ mins \\
\hline
\end{tabular}

Table 23 shows that building a second runway at Gatwick almost doubles the airport's capacity and increases the capacity of London airports by $22 \%$.

Table 23 - Comparing the capacity of Gatwick Airport. New runway simulations versus the current situation.

\begin{tabular}{|l|l|l|l|l|}
\hline & $\begin{array}{l}\text { Current } \\
\text { situation }\end{array}$ & $\begin{array}{l}\text { Gatwick new } \\
\text { runway }\end{array}$ & Difference & Change \\
\hline
\end{tabular}




\begin{tabular}{|l|l|l|l|l|}
\hline & capacity & capacity & & \\
\hline Gatwick & 57.2 & 114.1 & 56.9 & $99.5 \%$ \\
\hline $\begin{array}{l}\text { All London } \\
\text { Airports }\end{array}$ & 262.6 & 319.5 & 56.9 & $21.7 \%$ \\
\hline
\end{tabular}

\subsection{2nd runway at Stansted}

Stansted's location in rural Essex means that it is theoretically the easiest to expand.

The airport's 2006 interim master plan (Stansted Airport, 2006), indicated that a new runway could be built to the south east of the existing runway and it is this configuration which we use for simulation. It is assumed that the new runway has identical dimensions and can support the same traffic mix as the existing runway.

Table 24 shows the results of the simulations for Stansted with the second runway.

Table 24 - Simulations for Stansted second runway

\begin{tabular}{|r|r|r|r|l|r|}
\hline Simulation & \multicolumn{1}{l|l}{$\begin{array}{l}\text { 1 } \\
\text { runway } \\
\text { Arrivals }\end{array}$} & $\begin{array}{l}\mathbf{1}^{\text {st }} \text { runway } \\
\text { Departures }\end{array}$ & $\begin{array}{l}\text { 年 } \\
\text { runway } \\
\text { Arrivals }\end{array}$ & $\begin{array}{l}\text { Runway } \\
\text { Departures }\end{array}$ & \\
\hline $\mathbf{1}$ & 54 & 0 & 51 & 4 & 109 \\
\hline $\mathbf{2}$ & 53 & 2 & 51 & 3 & 109 \\
\hline $\mathbf{3}$ & 51 & 4 & 50 & 5 & 110 \\
\hline $\mathbf{4}$ & 52 & 2 & 49 & 7 & 110 \\
\hline $\mathbf{5}$ & 50 & 5 & 51 & 5 & 111 \\
\hline $\mathbf{6}$ & 50 & 5 & 51 & 5 & 111 \\
\hline $\mathbf{7}$ & 51 & 4 & 51 & 5 & 111 \\
\hline $\mathbf{8}$ & 52 & 3 & 50 & 6 & 111 \\
\hline $\mathbf{9}$ & 50 & 4 & 48 & 7 & 109 \\
\hline $\mathbf{1 0}$ & 51 & 3 & 52 & 2 & 108 \\
\hline Average & 51.4 & 3.2 & 50.4 & 4.9 & 109.9 \\
\hline
\end{tabular}


Table 25 shows how the Stansted second runway plans would change the capacity of Stansted and the London airports as a whole. This shows that the increase in capacity is very similar to that of a Heathrow third runway, which is potentially significant since expanding Stansted may be cheaper and more politically acceptable than developing Heathrow.

Table 25- Comparison between Stansted expansion capacity and current situation capacity

\begin{tabular}{|l|l|l|l|l|}
\hline & $\begin{array}{l}\text { Current } \\
\text { situation } \\
\text { capacity }\end{array}$ & $\begin{array}{l}\text { Capacity with } \\
\text { Stansted } \\
\text { expansion }\end{array}$ & Difference & $\begin{array}{l}\text { Percentage } \\
\text { Change }\end{array}$ \\
\hline Stansted & 54.6 & 109.9 & 55.3 & $101.3 \%$ \\
\hline $\begin{array}{l}\text { All London } \\
\text { Airports }\end{array}$ & 262.6 & 317.9 & 55.3 & $21.1 \%$ \\
\hline
\end{tabular}

\subsection{Optimising Heathrow}

The final option we consider here is the proposal to permanently adopt mixed mode operations at Heathrow. The advantage of this proposal is that it would not require any expensive or disruptive construction but it would impose an additional noise burden on airport residents.

The current runway alternation agreement "provides for one runway to be used by landing aircraft from 06:00 until 15:00 and the other runway to be used from 15:00 until after the last departure” (Heathrow Airport, 2013). What this means is that, while one runway can be freely used for arrivals and departures, the other runway can be used for departures only. While in an off-peak flow having one runway designated primarily for arrivals and one for departures may be fine, during peak periods commercial and operational imperatives dictate that the runways should be used to 
their maximum capacity. At present, therefore, Heathrow is not operating at its maximum capacity. The simulations that examine the effect of removing runway segregation adopt the same assumptions as for the current situation simulations. The simulations for runway 27L will be kept as the variables are unchanged. The simulations for runway $27 \mathrm{R}$ will be run as if the runway alternation agreement did not exist.

Table 26 details the outputs of these simulations. The unrestricted runway can handle around 54 movements per hour (40 arrivals, 14 departures). The simulations with the runway alternation agreement in the current situation section showed just under 40 departures were possible. Therefore removing the runway alternation agreement would raise Heathrow’s maximum capacity by around 14 movements per hour.

Table 26 - Simulations for Heathrow without runway alternation restrictions

\begin{tabular}{|r|r|r|r|r|r|}
\hline Simulation & \multicolumn{1}{l|l}{$\begin{array}{l}\text { 27L } \\
\text { Arrivals }\end{array}$} & $\begin{array}{l}\text { 27R } \\
\text { Departures }\end{array}$ & Arrivals & \multicolumn{2}{l|}{$\begin{array}{l}\text { Total } \\
\text { Departures }\end{array}$} \\
\hline $\mathbf{1}$ & 42 & 13 & 39 & 15 & 109 \\
\hline $\mathbf{2}$ & 40 & 15 & 43 & 12 & 110 \\
\hline $\mathbf{3}$ & 44 & 12 & 41 & 14 & 111 \\
\hline $\mathbf{4}$ & 41 & 15 & 40 & 14 & 110 \\
\hline $\mathbf{5}$ & 41 & 14 & 39 & 15 & 109 \\
\hline $\mathbf{6}$ & 42 & 12 & 39 & 14 & 107 \\
\hline $\mathbf{7}$ & 41 & 14 & 38 & 16 & 109 \\
\hline $\mathbf{8}$ & 42 & 11 & 42 & 12 & 107 \\
\hline $\mathbf{9}$ & 38 & 18 & 40 & 15 & 111 \\
\hline $\mathbf{1 0}$ & 41 & 13 & 37 & 16 & 107 \\
\hline Average & 41.2 & 13.7 & 39.8 & 14.3 & 109 \\
\hline
\end{tabular}


Table 27 shows the capacity of London and Heathrow with and without the runway alternation agreement. It can be seen that removal of this agreement would increase Heathrow’s capacity by $15 \%$ and London overall by over $5 \%$.

Table 27 - Comparison of Heathrow capacity with and without runway alternation

\begin{tabular}{|l|l|l|l|l|}
\hline & $\begin{array}{l}\text { Current } \\
\text { Situation } \\
\text { Capacity }\end{array}$ & $\begin{array}{l}\text { Capacity } \\
\text { without } \\
\text { runway } \\
\text { alternation }\end{array}$ & Difference & Change \\
\hline Heathrow & 95.1 & 109.0 & 13.9 & $14.6 \%$ \\
\hline London total & 262.6 & 276.5 & 13.9 & $5.29 \%$ \\
\hline
\end{tabular}

Significantly, this proposal affords a $14.6 \%$ capacity increase at the airport at minimal cost.

\section{Discussion}

The results of existing airport capacity simulations were presented in Section 3 and the results of simulations into five proposed capacity options were presented in Section 4. This section compares the relative capacity benefits of these proposals with the current situation to assess their relative merits and limitations.

Table 28 shows the results of all the proposals in this investigation. "N/A" has been given under costs where there are not any infrastructure costs, but other costs may exist. It is important to emphasise that these cost estimations are derived from publically available sources and are indicative only. The "year capacity constraints reach 2013 levels" column uses UK Department for Transport estimates to see at which point demand reaches the same proportion of supply as in 2013. 
Table 28 - The proposals compared

\begin{tabular}{|l|l|l|l|l|}
\hline Proposal & Total Capacity & $\begin{array}{l}\text { Change in } \\
\text { capacity }\end{array}$ & $\begin{array}{l}\text { Year } \\
\text { capacity } \\
\text { constraints } \\
\text { reach 2013 } \\
\text { levels }\end{array}$ & $\begin{array}{l}\text { Estimated } \\
\text { cost }\end{array}$ \\
\hline $\begin{array}{l}\text { Current } \\
\text { Situation/ Do } \\
\text { nothing }\end{array}$ & 262.6 & $0 \%$ & 0 & 0 \\
\hline $\begin{array}{l}\text { Heathrow third } \\
\text { runway }\end{array}$ & 317.4 & $+20.9 \%$ & 2021 & $£ 10 \mathrm{bn}$ \\
\hline $\begin{array}{l}\text { Stansted } \\
\text { second } \\
\text { runway }\end{array}$ & 317.9 & $+21.1 \%$ & 2021 & $£ 2.7 \mathrm{bn}$ \\
\hline $\begin{array}{l}\text { Gatwick } \\
\text { second } \\
\text { runway }\end{array}$ & 319.5 & $+21.7 \%$ & 2021 & $£ 5 \mathrm{bn}$ \\
\hline $\begin{array}{l}\text { Thames } \\
\text { Estuary airport }\end{array}$ & 479.3 & $+26.43 \%$ & 2023 & $£ 10 \mathrm{bn}$ \\
\hline $\begin{array}{l}\text { Thames } \\
\text { Estuary airport } \\
\text { without LHR }\end{array}$ & 384.2 & $+52.5 \%$ & $2050+$ & $£ 50 \mathrm{bn}$ \\
\hline $\begin{array}{l}\text { LHR Westward } \\
\text { Expansion }\end{array}$ & 332.0 & $+46.3 \%$ & 2033 & $£ 50 \mathrm{bn}$ \\
\hline $\begin{array}{l}\text { No runway } \\
\text { alternation at } \\
\text { LHR }\end{array}$ & 276.5 & $+\mathrm{A} \%$ & 2015 & \\
\hline & & +5.3 & & \\
\hline
\end{tabular}

All proposals to add a new runway increase the capacity by around $20 \%$. All the proposals that do not involve the construction of a new runway are comparatively ineffective at increasing runway capacity. 
The proposal to remove the runway alternation agreement at Heathrow increases total capacity by just over $5 \%$. This proposal should be easier to implement than any of the proposals requiring high levels of construction. There is potentially a problem that extra terminal capacity would be needed and therefore this may not be a "free" proposal. There are also further issues, mainly concerning the effect on local residents.

The Thames Estuary proposal is by far the most effective at increasing capacity. However it also has the obvious disadvantages of being the most expensive. If the government believes that increasing capacity is of the highest priority regardless of cost, then this could be an option. The decision about whether or not to keep Heathrow should a new hub airport open will arguably not be down to capacity. It is more likely to be either a question of compromise (removing Heathrow to increase the proposals acceptability) or airspace congestion as a result of the proximity of the two airports. Overall, this proposal does provide an effective long-term solution to the capacity problem, but considering other factors, this option is perhaps not as attractive as some of the smaller expansion proposals.

The proposals to construct a second runway at Stansted and Gatwick both increase capacity but there is not a lot to choose between them in terms of capacity increases. If financial estimates are taken into account, then Stansted appears to offer the best value option. Stansted also has plenty of land around the airport to accommodate any expansion. 
The research findings suggest that all three airports have strong cases for a new runway. Gatwick offers the highest increase in capacity, Stansted arguably provides the best value for money and Heathrow is reportedly the preferred choice among certain business and aviation groups.

Constructing all three runways would cost in the region of £20bn but increase the capacity in the South East by around $62 \%$. This would offer a significant saving over the $£ 50$ bn cost of a new hub airport whilst maintaining much of the capacity increase.

Expanding Heathrow to the west, as per Leunig's proposal, would give a capacity increase of around $26 \%$ (only 5\% more than the Heathrow third runway proposal). However, more research needs to be carried out to assess the true costs of such a project, both financially and socially.

\section{Conclusion}

Through the use of Monte Carlo simulation, this paper has examined five proposals that have been advanced to address the issue of future airport capacity in London and the South East of England. While the exercise has provided figures for current and potential future capacity at individual airports and across the three main London airports it does not advocate any particular develop. Indeed, we are acutely aware that any future decision about UK airport capacity needs to consider not only the practicalities of airport operations and optimal airfield configurations and locations but also the myriad socio-economic and environmental implications of any development at both local and global scales. 


\section{References}

Airport Coordination Ltd (2010), "LGW W10 Start Of Season Report", Available at: $<$ http://www.acluk.org/UserFiles/File/LGW\%20W10\%20START\%20OF\%20SEASON\%20REPORT _1.pdf>, [Accessed 03.03.2013]

Airport Coordination Ltd (2012a), "LGW S12 Start of Season Report", Available at: $<$ http://www.acl-

uk.org/UserFiles/File/LGW\%20S12\%20Start\%20of\%20season\%20report_V6.pdf>, [Accessed 11.03.2013]

Airport Coordination Ltd (2012b), "STN S12 Start of Season Report", Available at: $<$ http://www.acl-uk.org/UserFiles/File/STN_S12_Start_of_season_report2.pdf> [Accessed 16.03.2013]

Airport Coordination Ltd (2013), “LTN S13 Start of Season Report”, Available at: <http://www.acl-uk.org/UserFiles/File/LTN_S13_START_SEASON_REPORT.pdf> [Accessed 16.03.2013]

BBC (2012a), "Heathrow expansion: The alternatives to a third runway", Available at: <http://www.bbc.co.uk/news/uk-19570653>, [Accessed 22.03.2013]

BBC (2012b), "New Thames Estuary Airport Proposal Unveiled", Available at: <http://www.bbc.co.uk/news/uk-england-19577410>, [Accessed 04.04.2013]

Heathrow Airport (2010a), "BAA Airports Traffic Statistics 2010 Annual Review", Available at:

$<$ http://www.heathrowairport.com/static/Heathrow/Downloads/PDF/Traffic_Statistics -2010.pdf>, [Accessed 03.03.2013]

Heathrow Airport (2010b), "Patterns of Traffic 2010", Available at $<$ http://www.heathrowairport.com/static/Heathrow/Downloads/PDF/Patterns_of_Traf fic-2010.pdf>, [Accessed 10.03.2013] 
Heathrow Airport (2013), "Runway Alternation", Available at:

$<$ http://www.heathrowairport.com/noise/what-we-do-about-it/measures-already-inplace/runway-use/runway-alternation> [Accessed 08.03.2013]

ICAO (International Civil Aviation Organisation), (1999), "Aerodrome Standards", Available at:

[http://legacy.icao.int/fsix/_Library/Manual\%20Aerodrome\%20Stds.pdf], Last Accessed 17/8/13

Leunig, T (2012), "Bigger and Quieter: The right answer for Aviation", Policy Exchange, Available at:

[http://www.policyexchange.org.uk/images/publications/bigger\%20and\%20quieter.pd f], Last Accessed 20/8/13]

Pitfield, D.E., Jerrard, E.A. (1999), "Monte Carlo comes to Rome: A note on the estimation of unconstrained runway capacity at Rome Fiumucino Airport", Journal of Air Transport Management 5 (4), 185-192

Stansted Airport (BAA) (2006), "Interim Masterplan", Available at:

$<$ http://www.stanstedairport.com/static/Stansted/Downloads/PDF/STN_interim_mast erplan.pdf $>$ [Accessed 01.04.2013] 